\title{
The Bombing of The King David Hotel, July 1946*
}

\author{
Professor Bruce Hoffman, \\ Georgetown University, Washington, D.C.
}

\begin{abstract}
On July 22, 1946, the Irgun Zvai Le'umi (National Military Organization) a Jewish terrorist organization opposed to Britain's continued rule of Palestine, bombed Jerusalem's King David Hotel. The incident has always been controversial given the fact that the facility was not an ordinary hotel, but also the nerve center of British rule over that country-housing its military headquarters, intelligence stations, and government secretariat. Further, at the time it was claimed that warnings were issued to evacuate the hotel that British officials callously ignored. This article addresses three key questions surrounding the bombing: Was the King David Hotel in fact a legitimate military target? Were warnings in fact given to evacuate the hotel? And, if so, why wasn't the hotel evacuated? The answers, while critical in reaching an accurate accounting and factual understanding of a highly controversial event, interestingly also shed light on the efficacy and morality of terrorism as an instrument of national liberation and agent of political change.
\end{abstract}

Key words: Terrorism, Irgun Zvai Le'umi, Etzel, Menachem Begin, King David Hotel, British Mandate for Palestine

- This article incorporates material first published in the author's Anonymous Soldiers: The Struggle for Israel, 1917-1947 (New York: Knopf, 2015). This material pertains to the specific details of the bombing, its planning, logistics, and execution. The overall argument and structure is materially different from that which appears in Anonymous Soldiers. 
The Second Lebanon War was little more than a week old when, in July 2006, a ceremony was held at Jerusalem's King David Hotel to mark the $60^{\text {th }}$ anniversary of its bombing. A plaque affixed to the wrought iron fence outside the hotel's southwest wing was unveiled. In white letters against a blue background, the colors of the Israeli flag, it read

\section{King David Hotel}

The hotel housed the British Mandate Secretariat as well as the Army Headquarters. On July 1946, Irgun fighters, at the order of the Hebrew Resistance Movement, planted explosives in the basement. Warning phone calls had been made urging the hotel's occupants to leave immediately. For reasons known only to the British the hotel was not evacuated, and after 25 minutes, the bombs exploded, and to the Irgun's regret and dismay 91 persons were killed.

The plaque's wording prompted protests from both the British ambassador in Tel Aviv and consul-general in Jerusalem. "We do not think that it is right for an act of terrorism, which led to the loss of many lives to be commemorated," Simon McDonald and John Jenkins wrote to the Jerusalem Municipality, "Not only had no warning been given, they stated, but even if it had "this does not absolve those who planted the bomb from responsibility for the deaths." ${ }^{1}$ Seeking to avoid a diplomatic incident, the city complied and shortly afterwards a new plaque with a slightly amended version of those events appeared. ${ }^{2}$ The relevant portion now, albeit ungrammatically, states

Warning phone calls has [sic] been made, to the hotel's dispatch, the "Palestine Post" and the French Consulate, urging the hotel's occupants to leave immediately. The hotel was not evacuated, and after 25 minutes, the bombs exploded. The entire western wing [sic] was destroyed and to the Irgun's regret 92 [sic] persons were killed. 3 
The curiously revised figure of 92 deaths, included an Irgun fighter who died inside the hotel as a result of a gun battle with British troops. ${ }^{4}$

The irony of a decades-old controversy surfacing at the same time that Israel was battling Hezbollah in Lebanon was not lost on the participants at a conference held at the nearby Menachem Begin Heritage Centre to coincide with the anniversary and plaque's unveiling. "It's very important to make the distinction between terror groups and freedom fighters, and between terror action and legitimate military action," the current Israeli Prime Minister Benjamin Netanyahu argued in a speech to the gathering. "Imagine that Hamas or Hezbollah would call the military headquarters in Tel Aviv and say, 'We have placed a bomb and we are asking you to evacuate the area'." 5 Indeed, Menachem Begin, one of Netanyahu's ideological mentors and predecessors as prime minister and, who at the time commanded the Irgun Zvai Leumi, or National Military Organization, the group responsible for the bombing, always denied that their intention in attacking the King David was to harm anyone. "We did not want to hurt one living soul," he repeatedly claimed. This was why, Begin insisted, the Irgun affixed timers to the bombs so that the hotel could be evacuated and had also set off a small, diversionary explosion across the street to clear the area before issuing the three separate warnings that the plaque cites. ${ }^{6}$ Yet, despite all these precautions, tragedy nonetheless ensued.

Three questions continue to be at the heart of a dispute that has raged for more than a half century:

- Was the King David Hotel in fact a legitimate military target?

- Were warnings given to evacuate the hotel? And,

- If so, why wasn't the hotel evacuated?

The answers, while critical in reaching an accurate accounting and factual understanding of a highly controversial event, interestingly also shed light on the efficacy and morality of terrorism as an instrument of national liberation and agent of political change. 


\section{WAS THE KING DAVID HOTEL A LEGITIMATE MILITARY TARGET?}

There was no other place in 1940s Palestine like Jerusalem's King David Hotel. Built during the 1929 riots in a luxurious manner meant, in the words of its Swiss interior designer to "evoke by reminiscence, the ancient Semitic style and the ambience of the glorious period of King David,"7 Briton, Jew, and Arab, along with a glittering array of visiting potentates, dignitaries, and the well-heeled, regularly congregated at its popular bar; dined and danced in its basement nightclub, La Regence; or took tea in the aptly named Grand Lobby. The uncontested cynosure of the country's social life, the King David was also the nerve center of British rule: housing the government secretariat, army headquarters, and the local offices of Britain's various military and civilian security and intelligence services. At the height of the Arab Rebellion nearly a decade before, the British Army had requisitioned the hotel's fourth floor for use as its headquarters. Shortly afterward, the Palestine Government took over the ground floor, mezzanine level, and the three remaining upper floors of the hotel's south wing for its secretariat. Fewer than a third of the grand hotel's rooms remained for civilian guests and these were all located in the center and north wings of the hotel on the first two floors only.8

The hotel thus incongruously remained open to the public even though it was ringed with barbed wire defenses, searchlights, machine gun pits, checkpoints, roadblocks, armored cars, radio police vans, and continuous patrols. Indeed, the heavy foot traffic of both British officers coming in and out of headquarters and government officials popping over from the Secretariat for a meal, a drink at the bar, or tea in the lobby, created a frisson of importance and intrigue that attracted diplomats, spies, journalists and, evidently, terrorists as well who mixed with the hotel's guests and other civilian visitors. ${ }^{9}$

For all these reasons-its name recognition as a Jerusalem landmark, as the seat of British power in Palestine, and because of its continued accessibility to the public-the King David, despite the two hundred soldiers who worked there and the four hundred more bivouacked 
three hundred yards away, ${ }^{10}$ presented an irresistible target to the Irgun. ${ }^{11}$

The Irgun, it should be explained, was only one of three illegal Jewish movements active in Palestine at that time. The others were the Haganah-Hebrew for defense-and the Lohamei Herut Yisrael-Freedom Fighters for Israel, known to Jews by its Hebrew acronym, Lehi, and to the British as the Stern Gang. The Haganah was the largest and most restrained of the three. It was primarily a self-defense force, conceived as the nucleus of a future Jewish army for a future Jewish state. ${ }^{12}$ It would be incorrect to label the Haganah a terrorist organization. However, both the Irgun and Lehi were. More to the point, since the end of World War II all three organizations had been temporarily united as the "Hebrew Resistance Movement" referred to by the King David plague.

According to Begin, there was a fourth, equally critical, objective in targeting the hotel. The previous month, in a major British military operation against the Jewish leadership in Palestine, the authorities had seized highly sensitive documents directly implicating the Haganah and its political masters in the Jewish Agency with the resistance movement. The Haganah believed that these papers were stored in the British intelligence offices located in the King David and hence hoped that the Irgun's bombs would destroy the incriminating material.

\section{WERE WARNINGS ISSUED?}

At approximately 11:45 A.M. on July $22^{\text {nd }} 1946$, a stolen delivery truck pulled up to the basement service entrance at the front of the King David Hotel. An Arab laborer wearing the blue overalls and robe typical of such workers alighted and approached the clerk sitting at the door who asked to see his delivery order. The Arab instead produced a pistol and ordered the clerk into a nearby office where he and his fellow employees were held at gunpoint. Meanwhile, a second laborer strode from the truck into the basement and began gathering up whatever other hotel staff he could find, who were then herded into the kitchen and similarly kept under guard. 
The remaining four Irgun fighters now began to unload seven large milk churns that they carried into La Regence, the hotel's chic nightclub located in the basement beneath its southwest wing. Each contained approximately fifty pounds of high explosive. The operation's commander, known by his nom de guerre, Gideon, supervised their placement alongside the columns supporting the six floors above. When he was satisfied that they were properly positioned, Gideon wrapped detonating cord around the churns, set the timing devices, and activated the booby-trap mechanisms that the Irgun had designed to prevent the bombs from being tampered with. Signs printed in English, Arabic, and Hebrew warning "MINES-DO NOT TOUCH" were then attached to each milk churn. It was just a few minutes before noon and everything was going exactly according to plan. ${ }^{13}$

The Irgun team left La Regence and was proceeding back down the corridor towards the basement exit when they were confronted by a British Army officer. A fierce struggle ensued as two of the intruders grappled with the young captain, who was dragged flailing and kicking towards the kitchen. The bloodied officer, however, broke free of his assailants and tried to escape up the service staircase to the hotel lobby. One of the Irgun men raised his revolver and fired at point blank range: the officer staggered up a few more steps and then collapsed-mortally wounded. ${ }^{14}$ And, with that, the Irgun's plan unraveled.

An Irgun fighter guarding the hotel staff in the kitchen, distracted by the sounds of the hallway scuffle and gun shot, failed to notice that one of the clerks had inched his way over to an alarm button set in the wall, which he was frantically pressing. The distress signal was received at 12:15 P.M. in the Jerusalem District Police Wireless Transmission Room, on the Mamillah Road, about a quarter of a mile down the street from the King David, and a police radio van was duly dispatched to the hotel.

By now, Military Police were rushing both downstairs and out of the hotel's main entrance towards the sunken driveway leading to the service entrance. They arrived just as Gideon and his men emerged from the basement. A gun battle erupted in which two of the assault team 
were fatally wounded. Forced to abandon the truck as bullets rained down upon them, the men fled on foot through the hotel's garden in the direction of the old City. They piled into a waiting taxi, that had been parked in front of the French Consulate as a back-up escape vehicle, and sped away.

At that moment, a small diversionary bomb left by another Irgun unit outside an Arab-owned souvenir shop located next to the YMCA, directly across the street from the King David's southern wing, exploded.15 Its purpose, Begin later explained was to "make a big noise and disperse the people."16 The device, however, was considerably more powerful than the Irgun commander recalled or perhaps had even been intended. It not only damaged the shop but also shattered the windows of a passing Number Four bus: injuring several of its Arab passengers who were taken to the Secretariat to be treated for their wounds. The explosion also automatically triggered the police municipal alarm system operated by the Jerusalem District Police Control Room. Accordingly, sirens now blared throughout the downtown city center warning that a terrorist attack had occurred. ${ }^{17}$ All vehicular traffic immediately came to a stop and all government and military facilities went into a lock-down mode. ${ }^{18}$

Meanwhile, a young woman had been waiting patiently by a public telephone in an Armenian-owned pharmacy just down the road. Upon hearing the sound of the diversionary bomb, she recalls immediately dialing the King David's number. Obeying the instructions that her commander, had given her, Adina Hay-Nissan, a member of the Irgun's Jerusalem branch, spoke quickly in English, telling the switchboard operator who answered her call: “This is the Jewish Resistance Movement, we have planted bombs in the hotel. Please vacate it immediately. You have been warned." She repeated the message in Hebrew and hung up. Hay-Nissan then ran through the side streets to King George V Street where she entered a telephone booth and rang the French Consulate. Speaking only in English this time, Hay-Nissan told the person on the other end of the line to open all the windows in the building so that they would not be shattered by an explosion. Finally, she ran to a telephone booth across the street from the central bus 
station on Jaffa Road and called the Palestine Post's office. Speaking in Hebrew, she repeated her warning about an impending explosion at the King David and told the operator to inform the hotel that it should be evacuated immediately. Hay-Nissan believes that she placed the last call no more than ten minutes after the diversionary bomb had exploded. ${ }^{19}$

At 12:37 the bombs concealed inside the seven milk churns detonated-ripping the stone façade from the King David and slicing through the six floors of government and military offices that then collapsed in a massive heap of shattered glass, broken masonry, and crushed, lifeless bodies. ${ }^{20}$ "The chandelier fell down on my desk and the room filled with dust and smoke," the Chief secretary of the Palestine Government, Sir John Shaw, recalled of the explosion's force.

I went out into the corridor and it was black as soot. You couldn't see your hand in front of your face. I walked long [sic] the corridor, with one hand to guide me, when suddenly I saw a yawning chasm under my feet, almost the whole depth of the building, from the fourth floor to the ground. ${ }^{21}$

Ninety-one persons were killed and nearly seventy others injured. The dead included 41 Arabs, 28 Britons, 17 Jews, as well as two Armenians, a Russian, an Egyptian, and a Greek national. Among them were sixteen senior government officials but many more low-level clerks and typists, canteen workers and hotel employees, as well as five members of the public who happened to be in the hotel or on the street outside at the time of the explosion. ${ }^{22}$ A dozen of the slain were women. Serving military personnel accounted for 13 of the fatalities. ${ }^{23}$ More than two-thirds of the Secretariat's entire staff was either killed or wounded. ${ }^{24}$ Hence, even if the King David was a legitimate military target, the overwhelming majority of victims were clearly civilians.

"Even the centuries-old turbulent annals of the Holy Land record few crimes worse then the outrage perpetrated by the Irgun zvai Leumi on the $22^{\text {nd }}$ July," the High Commissioner for Palestine, General Sir Alan Cunningham reported to the Colonial Secretary, George Hall. ${ }^{25}$ Indeed, for decades to come the Irgun's bombing of the King David Hotel would hold the infamous distinction as the most lethal terrorist attack in 
history: surpassed only in 1983 with the suicide bomb attack on the U.S. Marine barracks in Beirut, Lebanon by the same fanatical Shi'a terrorist organization that Israel was battling when the plaque was unveiled in 2006. It is perhaps because of this nefarious record that the bombing of the King David Hotel has always been shrouded in controversy. ${ }^{26}$ Blame for the horrific loss of life and catastrophic injuries has been variously laid on the Irgun, the Haganah, the British, and indeed on Shaw himself. It has been voiced by Briton, Jew, and Arab alike as well as by those intent on proving that Jewish terrorism has historically been no less sanguinary or abominable than its modern-day Islamic counterpart.

WERE THE WARNINGS NOT RECEIVED OR IGNORED?

"Why was the King David Hotel not evacuated?" Begin asked six years later in his memoir of the Irgun's struggle, The Revolt. "In this tragic chapter," he claims, "there are certain facts which are beyond all doubt": first, that the Irgun's warnings were inexplicably ignored; and, second, that the hotel's evacuation was specifically prevented. "[T]here is reason to believe," the Irgun leader continues, "that a specific order was given, by someone in authority, that the warning to leave the hotel should be ignored. Why was this stupid order given? Who was responsible for it?"27 Although Begin provides no answers, his version of events-as the controversy over the wording of the anniversary plaque evidences-has assumed almost totemic importance in the mythology of both the Irgun's struggle and the history of prestate Israel.

The problem is that, like Begin's own account of the bombing itself, which claims that "twenty-five or twenty-seven minutes . . . elapsed from the receipt of the warnings to the moment of the explosion," 28 this purported statement of fact is not only inaccurate, but also perpetuates an image of British official malfeasance that is as false as it is self-serving.

Its provenance can be traced directly to the Irgun's own acknowledgement of responsibility for the bombing in the form of a brief statement distributed to newspaper offices in Jerusalem the 
following night. ${ }^{29}$ The communiqué unabashedly asserts that "The tragedy which occurred in the civil offices was not caused by Jewish soldiers who carried out their duty with soldierly courage and self-sacrifice, but by the British oppressors who disregarded the warning." In support of this claim, the Irgun stated that it had given ample warning to the authorities via three telephone calls made between $12: 10$ and $12: 15$ as well as from the small diversionary bomb that exploded across the street from the hotel, which was intended "to notify the guests so that they may leave the hotel and to passers-by in the neighbourhood." Accordingly, the document concludes, "if the announcement of the British liars is correct, the big explosion occurred at 12.37, meaning that they still had twenty minutes to clear the building. The responsibility for the loss of life among the civil population [therefore] falls entirely on them."30

Even in Palestine's pyretic atmosphere, with suspicion and hatred of Britain already rampant, the Irgun's shameless effort to absolve itself by in effect blaming the victim, fell on mostly deaf ears. ${ }^{31}$ The Hebrew press was particularly unsparing in the opprobrium heaped on the Irgun.

None of this, however, mattered to Begin who brushed off much of the criticism as "journalistic hysteria and self-abasement." ${ }^{32}$ What did wound him profoundly though was the totally unexpected, searing rebuke delivered by the Haganah. Disregarding completely the fact that the Haganah had both ordered and approved the King David operation in hopes of destroying the documents recently seized by British authorities that incriminated the entire Jewish leadership in underground violence, the Haganah broadcast a statement over its clandestine radio station Kol Israel on 23 July denouncing the "heavy loss of life caused by the dissidents' operation at the King David Hotel." ${ }^{33}$ Hearing the report, the Irgun commander was dumbstruck. As Begin pondered the matter, a courier sent by Israel Galili, the Haganah's commander, arrived at his door bearing an urgent message requesting that they meet at 9:00 that same evening. "What does this mean?" Begin recalled asking his Haganah counterpart. "Don't you know what and who caused the 'heavy toll?' Why do you denounce us? The plan was agreed between us, our men 
carried out their instructions precisely, the warning was given-why don't you tell the truth?"

Galili prevaricated and instead regaled Begin with a story about a member of the Haganah's Information Service who had learned of a conversation that had supposedly taken place between a senior police officer and a senior British official shortly before the bombing. Upon being informed of the Irgun's warning, this official-whom Galili's mysterious informant believed was the Chief secretary-had replied that he was not here to take orders from Jews, but to give them: thus preventing the hotel's evacuation. ${ }^{34}$ The same argument had been presented to the MI5 station chief in Palestine and to his American counterpart as well the previous day by the Haganah liaison officer. It was dismissed out of hand by the MI5 station chief as a craven effort "both to discredit Sir John Shaw, and to place on British heads guilt for the deaths at the King David Hotel. The Agency are, in other words," he correctly intuited, "attempting in some measure to find excuses for the Irgun Zvai Leumi."35

Begin and his followers, however, swallowed the story whole. Desperate to cleanse their blood-stained hands and deflect blame onto any conveniently plausible target, the Irgun wrapped their arms around this second-hand bit of tittle-tattle and embraced it with a fervor that belied its questionable pedigree much less the motive of the person purveying it. ${ }^{36}$

When, to mark the bombing's first anniversary the Irgun issued a pamphlet titled, "The Truth about the King David," this canard was prominently featured. "A representative of the 'Resistance Movement' told us privately," the pamphlet claimed, "that shaw replied to the British Police Officer who informed him of our last telephonic warning, 'I do not take orders from Jews-I give them orders.' "37

Nor did it take long for the allegation to appear in commercial book form. In 1947, a book titled, Palestine Underground: The Story of Jewish Resistance by J. Borisov, the pseudonym of an Irgun propagandist whom, the book's "Introduction" explains "was in a position to secure first-hand information about the resistance," was published in America. Borisov cites "abundant evidence" that British officials ignored the 
Irgun's warnings-but provides nothing but innuendo to support his claim. Regardless, he brashly concludes that "The heavy loss of life was caused exclusively by Sir John's vain pride and obstinacy."38 This charge was repeated in Britain the following year with the publication of a revised edition of the 1938 book, The Rape of Palestine. Written by William B. Ziff, a prominent, pro-Irgun JewishAmerican publisher, the new version included a footnote stating that the Irgun gave the British a full thirty minutes to evacuate the King David. It then alleges that "Shaw, the First Secretary of the Administration, chose to forbid any of the other officials to leave the building, though he himself did. The result was considerable loss of life." 39

While there is no evidence that Shaw was aware of the Borisov book, when The Rape of Palestine appeared, he sued Ziff and his British publisher for libel. The case was heard in the High Court of Justice. Investigators hired by the defense were unable to discover any evidence or witnesses in Israel to support Ziff's allegation. The court decided the case in Shaw's favor: ordering the author and his publisher to withdraw the book from publication, "unreservedly" correct "all imputations" of Shaw's character, and apologize to the former Chief Secretary for slandering him. ${ }^{40}$

None of this, however, deterred Begin and his apologists from continuing to peddle this calumny-as the plaque outside the King David Hotel today attests. For example, volume four of the Irgun's official history, Battle for Freedom: The Irgun Zvai Le'umi, published in 1975, not only repeats the story and Shaw's alleged reply-citing Galili as the source-but also grafts onto it the additional allegation that the Chief Secretary deliberately prevented the evacuation by ordering British soldiers to open fire "in the direction of those trying to leave" the hotel. The author, David Niv, does not explain how, if Shaw had refused to communicate the warning to the rest of the secretariat, as is alleged, any of the staff would have known of the warning and therefore attempted to leave the hotel ${ }^{41}$ 
THE WARNINGS WERE NEVER PASSED TO THE BRITISH AUTHORITIES

The truth of the matter is both more complex and more complicated than any of the above explanations allow. While it is true that warning calls to evacuate the King David were received by both the hotel switchboard and an operator at the Palestine Post-a fact confirmed at the time by U.S. intelligence officers in Jerusalem ${ }^{42}$-and were in turn communicated to the hotel's assistant manager, Emile Soutter, the jumble of events and noise and confusion simultaneously occurring inside and outside the hotel-including the shootout in the basement between the Irgun assault team and British soldiers as well as the running gun battle across the hotel's garden that followed, the diversionary explosion outside the souvenir shop across the street, and the sirens sounding the terrorist alarm, only to shortly afterwards issue the "all clear"-all conspired to ensure that word was never passed to Shaw or any other person in authority in time. ${ }^{43}$

But, at the same time, the Irgun's and Begin's various claims to have provided twenty-two, twenty-five, twenty-seven, and thirty minute windows of time between the first call to the hotel and the bombs' explosion have never been proven. Nor has the British Army's official histories' assertion that the warnings were not received until either a minute or even a second before the blast. Rather, the first warning call appears to have been made to the hotel at 12:27-ten minutes before the blast-with the second conveyed by the Palestine Post's operator to the King David's switchboard at 12:32-five minutes before the explosion.

Soutter was in fact made aware of both calls, but chose to take no further action for two reasons. The first was that British government offices in Jerusalem had long been subjected to bomb threats which had proven to be nothing more than disruptive hoaxes. Hence, the assistant hotel manager was not overly alarmed by the calls and, in any event, did not wish to cause potential panic by ordering the building's evacuation. Soutter and his wife had themselves experienced two such hoaxes the previous month while waiting in line at a nearby Barclay's Bank branch and then at the main post office on the Jaffa Road. Both incidents had turned shambolic as patrons and employees alike had 
rushed for the exits and he did not want to be responsible for a similar fiasco at the King David. It must also be said, that because so many Jews either worked in the King David or regularly visited it, there was a false sense of security that terrorists would never dare to attack a target that might in any way cause Jewish casualties. This proved to be a fatal miscalculation. ${ }^{44}$

Good intelligence, moreover, was often in woefully short supply in Palestine. ${ }^{45}$ For example, although as recently as May 1946 the police had warned of an Irgun plot to blow up the Secretariat, the vagueness of the information coupled with the fact that since December 1945 several other such threats against the King David had failed to materialize, led to its dismissal as well.46 Accordingly, the lack of more specific intelligence, along with the conviction that the Irgun would never undertake an operation that risked harming Jews, proved disastrous. ${ }^{47}$

Ironically, the sad truth of the matter is that even if the King David had been evacuated, as the Irgun had intended, the casualty toll would likely have been even greater. Those passersby and personnel who had already gathered in front the hotel before the main explosion were mercilessly cut down by flying shards of glass and bits of masonry hurled in their direction by the force of the blast. Accordingly, had everyone in the building been standing on the pavement in front of the YMCA across the street from the King David, still more people would doubtless have been killed or hurt. ${ }^{48}$ Begin and the Irgun apparently had neglected to consider this possibility in planning the attack. Therefore, arguments that the Irgun gave warning of the impending explosion and that the group's proclaimed policy was to avoid harming civilians, in the final analysis cannot absolve Begin and his organization of responsibility for the loss of life and harm that their bombs inflicted.

Finally, in the days preceding the bombing, British intelligence may have been the victim of a colossally successful Irgun deception operation. On 9 July, H.A.R. "Kim" Philby, a senior officer in the Secret Intelligence Service (MI6), who would later be unmasked as a Soviet spy, had written to the Foreign office with information about an 
Irgun plot to attack Britain's Minister to the Levant States based in Beirut, his staff, and the legation buildings. According to the MI6 station chief in Lebanon, an Irgun hit team of recently demobilized British Army soldiers had arrived the previous month for this purpose. ${ }^{49}$ The threat was taken sufficiently seriously by MI5 and the Palestine Government to warrant sending both Sir Gyles Isham, its Jerusalem station chief, and Arthur Giles, the head of the Palestine Police's equivalent of Special Branch, to Lebanon. ${ }^{50}$ Reflecting on this episode nearly thirty years later, Isham was convinced that it was a deliberate Irgun ploy to ensure that the country's two most senior intelligence officers would not be present in Palestine when the bombing on the King David occurred. ${ }^{51}$ The threatened attacks in Lebanon never materialized and nothing more was ever heard of that alleged plot.

\section{IMPACT, EFFECTS AND FINAL THOUGHTS}

The bombing of the King David evoked horror and umbrage back in London. Addressing the House of Commons, Prime Minister Clement Attlee termed it an "insane act of terrorism." Daniel Lipson, a Jewish member of the opposition Conservative Party, declared that the bombing brought "dishonor and shame to the name of Jew"; while his fellow Tory, the Earl of Winterton, described the Irgun "as vile and treacherous a foe as the Nazis." ${ }^{52}$ Comment in the press was identically condemnatory in tone, but significantly different in substance. For the first time, just as Begin had intended, ${ }^{53}$ doubt began to creep into the calculus of whether Britain should persevere in its stoic quest to achieve a just settlement of the Palestine problem. ${ }^{54}$ "Hopes that the teeth of terrorism had been drawn by recent arrests and discoveries of hidden arms dumps have been disappointed," the Daily Telegraph lamented. ${ }^{55}$ The Manchester Guardian likewise observed that the bombing "will be a shock to those who imagined that the Government's firmness had put a stop to Jewish terrorism and had brought about an easier situation in Palestine. In fact, the opposite is the truth . . ."56 And, echoing these same sentiments, the Times argued "it is more than ever clear that the present situation in Palestine cannot be permitted to continue . . ." ${ }^{57}$ 
Despite-or perhaps because of-the tragic loss of life, so far as the Irgun was concerned the bombing achieved its objective: attracting worldwide attention to the group's struggle and Palestine's worsening security. These reactions accorded perfectly with Begin's strategy to foster a climate of fear and alarm in Palestine so pervasive as to undermine confidence both in Palestine and in Britain over the government's ability to maintain order. "The very existence of an underground . . must in the end undermine the prestige of a colonial regime that lives by the legend of its omnipotence," Begin famously wrote. "Every attack which it fails to prevent is a blow at its standing. Even if the attack does not succeed, it makes a dent in that prestige, and that dent widens into a crack which is extended with every succeeding attack." 58

An integral and innovative part of the Irgun's strategy was Begin's use of daring and dramatic acts of violence-such as the King David Hotel bombing-to attract international attention to Palestine and thereby publicize simultaneously the zionists' grievances against Britain and their claims for statehood. In an era long before the advent of 24-hour cable news and instantaneous satellite-transmitted broadcasts, the Irgun deliberately attempted to appeal to a worldwide audience far beyond the immediate confines of the local struggle, beyond even the ruling regime's own homeland. In particular, the Irgun-like its non-violent and less violent zionist counterpartssought to generate sympathy and marshal support among powerful allies such as the Jewish community in the United States and its elected representatives in Congress and the White House, as well as among the delegates to the fledgling United Nations Organization, to bring pressure to bear on Britain to grant Jewish statehood.

The Irgun appears to have adopted and improved upon prior efforts by both the Irish Republicans since the 1850 s and Arab rebels in Palestine during the 1930 s respectively to "internationalize" their struggles. Each sought to appeal to and mobilize the support (both financial and material) of their constituencies-for the Irish, of their ethnic brethren in the United States; and, for the Palestinian Arabs in surrounding countries. ${ }^{59}$ The success of the Irgun's further 
use of this strategy, Begin claims, may be seen in the paucity of global coverage afforded to the civil war that had erupted in Greece after the Second World War, compared to that devoted to events in Palestine. Palestine, he wrote, had undeniably become a "centre of world interest. The revolt had made it so. It is a fact," Begin maintains,

that no partisan struggle had been so publicized throughout the world as was ours . . . The reports on our operations, under screaming headlines, covered the front pages of newspapers everywhere, particularly in the United States . . - The interest of the newspapers is the measure of the interest of the public. And the public-not only Jews but non-Jews too-were manifestly interested in the blows we were striking in Eretz Israel. ${ }^{60}$

The articulation of Begin's strategy in his book, The Revolt, first published in English in 1951, thus represents an important milestone in the evolution and "internationalization" of terrorism. ${ }^{61}$ Under his leadership, the Irgun deliberately sought an audiences far beyond the geographical confines of their campaign in Palestine. The Irgun's violence was specifically designed to attract attention in New York and Washington and Paris and Moscow as well as in London and Jerusalem. Begin's example appears to have subsequently resonated with other peoples elsewhere struggling against Western colonial domination and continued occupation of their lands in the decade following world War II. The leader of the anti-British guerrilla campaign in Cyprus, General George Grivas, adopted an identical strategy. Although there is no evidence that he ever read Begin's book or had studied the Irgun's campaign, the parallels between the two are unmistakable. ${ }^{62}$ The internationalization of Palestinian Arab terrorism that occurred in the 1960 s and 1970s would also appear to owe something to the quest for international attention and recognition that the Irgun's own terrorist campaign pioneered a quarter of a century earlier. ${ }^{63}$ And, the Brazilian revolutionary theorist Carlos Marighela's famous "Mini-Manual," the Handbook of Urban Guerrilla War, ${ }^{64}$ which was essential reading for the variety of left-wing terrorist organizations that arose both in Latin American and Western Europe during the 1960s and 1970s, embodies Begin's strategy of provoking the security forces in hopes of 
alienating the population from the authorities. More recently, when U.S. military forces invaded Afghanistan in 2001 they found a copy of Begin's seminal work, The Revolt, along with other books about the Jewish struggle and the Irgun's transformation from terrorist group pariah to a respectable political party, in the well-stocked library that al Qaeda maintained at one of its training facilities in that country. ${ }^{65}$

\section{BIBLIOGRAPHY}

“A Senseless Outrage," Times, 23 July 1946

al-Bahri, Nasser with Malbrunot, Georges. Guarding Bin Laden: My Life in al-Qaeda. Great Britain: Tim Man Press, 2013

Bell, J. Bowyer. Terror Out of Zion: Irgun Zvai Leumi, LEHI, and the Palestine Underground, 1929-1949. New York: St. Martin's Press, 1977

Begin, Menachem. The Revolt: Story of the Irgun. New York: Henry Schuman, 1951

Begin, Menachem. The Revolt: Story of the Irgun. Jerusalem: Steimatzky, 1977

Bethell, Nicholas. The Palestine Triangle: The Struggle between the British, the Jews, and the Arabs 1935-48. London: Andrew Deutsch, 1979

Borisov, J. Palestine Underground: The Story of the Jewish Resistance. Philadelphia: Judea, 1947

Briscoe, Robert (with Hatch, Alden). For The Life of Me. Boston \& Toronto: Little, Brown and Company, 1958

Brutton, Philip. A Captain's Mandate Palestine: 1946-48. London: Leo Cooper, 1996

Burleigh, Michael. Blood and Rage: A Cultural History of Terrorism. New York: HarperCollins, 2009.

Cavendish, Anthony. Inside Intelligence. London: Collins, 1990.

Clarke, Thurston. By Blood and Fire: The Attack on the King David Hotel. New York: G.P. Putnam's Sons, 1981 
Cohen, Michael J. Palestine: Retreat from the Mandate-The making of British policy, 1936-45. London: Paul Elek, 1978

Comay, Joan. "King of them all: 50 years of the King David Hotel," Jerusalem Post International Edition, 18 October 1981

Coogan, Tim Pat. The IRA: A History. Niwot, Colorado: Roberts Rinehart, 1993

Clutterbuck, Lindsay. "The Progenitors of Terrorism: Russian Revolutionaries or Extreme Irish Republicans?" Terrorism and Political Violence, vol. 16, no. 1 (Spring 2004)

"Crisis In Palestine," Manchester Guardian, 23 July 1946.

Dinur, Ben-Zion. Sefer Toldo Ha-Haganah (A History of the Haganah). Vol. 1. Tel Aviv: Ma'arhot, 1954-1972

Charles Foley (ed.), The Memoirs of General Grivas (London: London: Longmans, 1964)

French, David. The British Way in Counterinsurgency 1945-1967. Oxford: Oxford University Press, 2011

Golan, Aviezer and Shlomo Nakdimon. Begin. Jerusalem: Edanim, 1978

Grivas, General (trans. A. A. Pallis). Guerrilla Warfare and Eoka's Struggle. London: Longmans, 1964

Hacker, Frederick J. Crusaders, Criminals, Crazies: Terror and Terrorism in Our Time. New York: W. W. Norton, 1976

How The Terrorists Got In; Men Disguised as Bedouins 'Deliver the Milk'," Manchester Guardian, 23 July 1946; "Official Army H.Q. Account," Palestine Post, 23 July 1946

"La Regence"; Official Army H.Q. Account," Palestine Post, 23 July 1946

Parker, Ned and Farrell, Stephen. "British anger at terror celebration," terror celebration," Times (London), 20 July 2006

Niv, David. Ma'archot Ha-Irgun Ha-Zvai Ha-Leumi (Battle for Freedom: The Irgun Zvai Leumi). Vols. 1-5. Tel Aviv: Klausner Institute, 1975

Prince-Gibson, Eetta. "Reflective Truth," Jerusalem Post, 26 July 2006

Marighela, Carlos (trans. John Butt and Rosemary Sheed). For the Liberation of Brazil. Harmondsworth: Penguin, 1971

"Plain Murder," Daily Telegraph, 23 July 1946 
Porath, Y. The Palestinian Arab National Movement 1929-1939: From Riots to Rebellion, vol. ii 1929-1939. London: Frank Cass, 1977

Roman, Yadin. "The Grand Hotel of Jersualem," Eretz: The Magazine of Israel, no. 107 (February 2007)

Rose, Norman. 'A Senseless, Squalid War': Voices from Palestine 19451948. London: Bodley Head, 2009Trevor, Under The White Paper,

Shipler, David K. "Ex-Guerrillas Reminisce at the King David Hotel," New York Times 26 September 1981

Trevor, Daphne. Under the White Paper: Some Aspects of British Administration in Palestine from 1939-1947. Jerusalem: The Jerusalem Press, 1948

Walton, Calder. Empire of Secrets: British Intelligence, The Cold War And The Twilight of Empire. London: Harper Press, 2013

Wright, Lawrence. The Looming Tower: Al-Qaeda and the Road to 9/11. New York: Knopf, 2006

1 Quoted in Ned Parker and Stephen Farrell, "British anger at terror celebration," Times (London), 20 July 2006.

2 Ibid., and Eetta Prince-Gibson, "Reflective Truth," Jerusalem Post, 26 July 2006 .

3 Photograph of the current plaque by the author, July 2007 .

4 Prince-Gibson, "Reflective Truth."

5 Quoted in Parker and Farrell, "British anger at terror celebration."

6 Begin, The Revolt, p. 219. See also, Bethell, The Palestine Triangle, p. 261 .

7 Yadin Roman, "The Grand Hotel of Jersualem," Eretz: The Magazine Of Israel, no. 107 (February 2007), p. 33.

8 Clarke, By Blood \& Fire, p. 37. See also, Joan Comay, "King of them all: 50 years of the King David Hotel," Jerusalem Post International Edition, 18 October 1981; Roman, “The Grand Hotel of Jersualem," p. 35; and Sherman, Mandate Days, p. 165.

9 Ibid., pp. 36-38 \& 48-49; and, Montefiore, Jerusalem, p. 477.

10 Clarke, By Blood \& Fire, p. 29. 
11 Begin, The Revolt, p. 212; and, Aviezer and Nakdimon, Begin, p. 115 .

12 See the speech by Eliahu Golomb, the "father" of the Haganah and its first commander, who guided its transformation from an underground fighting force into a full-fledged army quoted in Ben-zion Dinur, Sefer Toldot Ha-Haganah (History of the Haganah) (Tel Aviv, 1954-1972), vol. i, p. 154 .

13 NA CO 537/2290 Letter, Assistant Inspector-General J.P.I. Fforde to Chief Secretary, 16 August 1946. See also, SAMEC Cunningham Papers I/1 Telegram, Barker to Hall, 22 July 1946; SAMEC Philip Morris Papers II/1 “La Regence," 13 December 1946; “How The Terrorists Got In; Men Disguised as Bedouins 'Deliver the Milk'," Manchester Guardian, 23 July 1946; "Official Army H.Q. Account," Palestine Post, 23 July 1946; Begin, The Revolt, pp. 218-219; Bethell, The Palestine Triangle, pp. 258-259; Clarke, By Blood \& Fire, pp. 163-166, 169, \& 180-181; and, Niv, Ma'archot Ha-Irgun, vol. iv, pp. 279-280.

14 NA CO 537/2290 Letter, Fforde to Shaw, 16 August 1946; ibid., Letter, Cunningham to Hall, 20 December 1946; SAMEC Cunningham Papers I/1 Telegram, Barker to Hall, 22 July 1946; SAMEC Philip Morris Papers II/1 "La Regence"; Official Army H.Q. Account," Palestine Post, 23 July 1946; Bethell, The Palestine Triangle, p. 259; Clarke, By Blood \& Fire, pp. 170, 172-176, \& 233; and, Niv, Ma'archot Ha-Irgun, vol. iv, p. 279. 15 NA CO 537/2290 Letter, Fforde to Shaw, 16 August 1946; Brutton, A Captain's Mandate, pp. 46-47; and, Clarke, By Blood \& Fire, pp. 188189 .

16 Quoted in Bethell, The Palestine Triangle, p. 260.

17 NA CO 537/2290 Letter, Fforde to Shaw, 16 August 1946; Aviezer and Nakdimon, Begin, p. 116; Bethell, The Palestine Triangle, pp. 261262; and, Clarke, By Blood \& Fire, pp. 188-189, 196-199\& 206-207.

18 Aviezer and Nakdimon, Begin, p. 116.

19 Quoted in Bethell, The Palestine Triangle, p. 261. See also, Shipler, “Ex-Guerrillas Reminisce at the King David Hotel." 
20 Ibid.; Bell, Terror Out of Zion, pp. 171-172; Clarke, By Blood \& Fire, pp. 200, 203-204; “41 Dead, 53 Injured, 52 Missing In Terrorist Attack on Secretariat," Palestine Post, 23 July 1946; and, Niv, Ma'archot Ha-Irgun, vol. iv, pp. 280-282.

21 Quoted in Bethell, The Palestine Triangle, pp. 262-263.

22 NA CO 537/2290 Letter, Fforde to Shaw, 16 August 1946.

23 NA CO 537/2290 Letter, Fforde to Shaw, 16 August 1946; and, RH Papers of Sir John Shaw Mss. Brit. Emp. S.456 containing Palestine Gazette, No. 150 , , 6 August 1946 .

24 RH Papers of Sir Robert Scott Mss. British Empire S.417(4) Letter, Scott to Mrs. Robert Scott (his mother), 28 July 1946; and NA CO 537/1708 Telegram, Cunningham to Hall, 3 August 1946.

25 NA CO 537/1708 Telegram, Cunningham to Hall, 3 August 1946.

26 See, for instance, David K. Shipler, "Ex-Guerrillas Reminisce at the King David Hotel," New York Times 26 September 1981 .

27 Quoted in Begin, The Revolt, pp. 220-221.

28 Ibid., p. 221 .

29 NARA RG 226 OSS 108A/NN3-226/92-1 Box 19, File 22, Folder 3 JERU-004, Notes on the King David Hotel Bombing, 24 July 1946. See also, NA WO 261/562 HQ British Troops in Palestine \& Transjordan, G Branch, Historical Record, July-September 1946: The Attack on the King David Hotel-22 July 1946; NA KV 5/36 Extract: Appreciation of situation Palestine, 24 July 1946; and, Ibid., Letter, S. Prescott for DSO, HQ Palestine, to Kellar, 27 July 1946.

30 NA KV 5/36 Irgun Issues "Communique On Attack," (no date).

31 See NARA RG 226 OSS 108A/NN3-226/92-1 Box 19, File 22, Folder 3 JERU-004, Report No. 518 First Reaction To Monday's Outrage, 23 July 1946; Ibid., OSS Notes on the King David Hotel Bombing, 24 July 1946; NA CO 537/1715 Letter, Robertson to Trafford-Smith, 29 July 1946; and, Trevor, Under The White Paper, p. 228.

32 Begin, The Revolt, p. 223.

33 Quoted in Begin, The Revolt, pp. 223-224. See also, Clarke, By Blood \& Fire, p. 243. 
34 Ibid., p. 224. See also, Bethell, The Palestine Triangle, p. 263; Clarke, By Blood \& Fire, p. 245; Aviezer and Nakdimon, Begin, p. 118; Niv, Ma'archot Ha-Irgun, vol. iv, p. 282

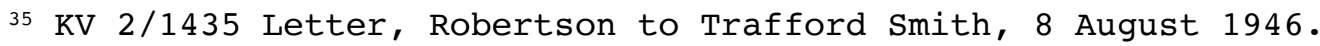
Interestingly, U.S. intelligence officers in Palestine reported having been approached by the "Jewish Agency's Intelligence Service" with the same exculpatory information about the bombing. See NARA RG 226 OSS 108A/NN3-226-92-1 Box 19, File 22, Folder 3 GP Palestine Report No. 535 Jewish Agency Intelligence Department Working On Evidence That [sic] Secretariat Was Duly Warned, 31 July 1946.

36 NA 5/36 Palestine: Jewish Reaction to blowing up of King David Hotel, 12 August 1946 .

37 Quoted in RH Catling Papers Memorandum On Jewish National Institutions In Acts of Violence, 1947, Appendix LVa, Letter J.P.I. Fforde, Assistant Inspector General, CID to Sir Henry Gurney, Chief Secretary, July 1947 containing “The Truth about the King David," National Military Organisation, 22 July 1947.

38 Quoted in Borisov, Palestine Underground, p. 133.

39 William B. Ziff, The Rape of Palestine (London: St. Botolph's, $1948)$, p. 486 .

40 RH Papers of Sir John Shaw High Court of Justice, King's Bench Division, The Hon. Mr. Justin Hilberry 1948 S.No. 3790 Sir John Shaw (P) V. Wm. B. Ziff, Donald George Port trading as Jason Press and S.T. Botolphs Publishing Co., Ltd., 12 April 1949. See also, Cavendish, Inside Intelligence, p. 19; Clarke, By Blood \& Fire, pp. 190-191 \& 260; and, Rose, "A Senseless, Squalid War," pp. 115-116.

41 Niv, Ma'archot Ha-Irgun Ha-Zvai Ha-Le'umi, vol. iv, pp. 282-283.

42 NARA RG 226 OSS 108A/NN3-226/92-1 Box 19, File 22, Folder 3 JERU-004, Notes on the King David Hotel Bombing, 24 July 1946 .

43 Clarke, By Blood \& Fire, pp. 204-205 \& 211-213.

44 SAMEC Papers of Lt. Gen. John D'Arcy GB165-0075 Letter, Barker to D'Arcy, 29 July 1946; and, Clarke, By Blood \& Fire, pp. 203-206\& 211-213.

45 French, The British Way in Counterinsurgency, p. 33 
46 See IWM Rymer-Jones Papers, pp. 132, 143-144\& \& 149; and, SAMEC Papers of Richard Crossman GB165-008 Letter, Shaw to Crossman, 2 August 1946.

47 NA CAB $128 / 6$ C.m. (46) $75^{\text {th }}$ Conclusions, 30 July 1946; SAMEC D'Arcy Papers Letter, Barker to D'Arcy, 29 July 1946; and, Ibid., Crossman Papers Letter, Shaw to Crossman, 2 August 1946.

48 NA CO 537/2290 Letter, Fforde to Shaw, 16 August 1946; and, ibid., Letter, Cunningham to Hall, 20 December 1946. See also, Clarke, By Blood \& Fire, p. 222; and, Rose, "A Senseless, Squalid War," p. 116.

49 NA KV 5/36 Letter, Philby to Bromley, 8 July 1946; Ibid., Foreign Office to Shone, 19 July 1946; and, Ibid., Shone to Foreign Office, 21 July 1946.

50 Ibid., Foreign Office to Shone, 19 July 1946.

51 Northamptonshire Record Office, Papers of Sir Gyles Isham I/184 Letter, Islam to Shaw, 15 January 1972 quoted in Wagner, “Britain and the Jewish Underground, 1944-46," p. 166.

52 Debates, House of Commons, vol. 425, cols. 1877-1880, 23 July 1946 .

53 Begin, The Revolt, p. 52 .

54 See, for instance, NA WO 261/562 Attitude In England To The Palestine Problem in Fortnightly Intelligence Newsletter No. 20. HQ, Palestine \& Transjordan, 22 July-4 August 1946; and, Sherman, Mandate Days, p. 183 .

55 "Plain Murder," Daily Telegraph, 23 July 1946.

56 “Crisis In Palestine," Manchester Guardian, 23 July 1946.

57 "A Senseless Outrage," Times, 23 July 1946.

58 Ibid., p. 52 .

59 See Robert Briscoe (with Alden Hatch), For The Life of Me (Boston \& Toronto: Little, Brown and Company, 1958), pp. 263-266 \& 294; Michael Burleigh, Blood and Rage: A Cultural History of Terrorism (New York: HarperCollins, 2009), p. 3; Michael J. Cohen, Palestine: Retreat from the Mandate-The making of British policy, 1936-45 (London: Paul Elek, 1978), pp. 18-31 \& 54-63; Lindsay Clutterbuck, “The Progenitors of Terrorism: Russian Revolutionaries or Extreme Irish Republicans?" 
Terrorism and Political Violence, vol. 16, no. 1 (Spring 2004), p. 163; Tim Pat Coogan, The IRA: A History (Niwot, Colorado: Roberts Rinehart, $1993)$, p. 11; Y. Porath, The Palestinian Arab National Movement 19291939: From Riots to Rebellion, vol. ii 1929-1939 (London: Frank Cass, 1977), pp. 199-216; and, Calder Walton, Empire of Secrets: British Intelligence, The Cold War And The Twilight of Empire (London: Harper Press, 2013), p. 101.

60 Begin, The Revolt, pp. 54-5.

${ }^{61}$ Menachem Begin, The Revolt: Story of The Irgun (New York: Henry Schuman: 1951).

62 Charles Foley (ed.), The Memoirs of General Grivas (London: London: Longmans, 1964), passim; and, General Grivas (trans. A. A. Pallis), Guerrilla Warfare and Eoka's Struggle (London: Longmans, $1964)$, passim.

${ }^{63}$ Frederick J. Hacker, Crusaders, Criminals, Crazies: Terror and Terrorism in Our Time (New York: W. W. Norton, 1976), pp. 72-73.

${ }^{64}$ Carlos Marighela (trans. John Butt and Rosemary Sheed), For the Liberation of Brazil (Harmondsworth: Penguin, 1971), pp. 61-97.

65 Nasser al-Bahri with Georges Malbrunot, Guarding Bin Laden: My Life in al-Qaeda (Great Britain: Tim Man Press, 2013) p. 77 ; and, Lawrence Wright, The Looming Tower: Al-Qaeda and the Road to 9/11 (New York: Knopf, 2006), p. 303 . 